\title{
Application of different nitrogen doses to increase nitrogen efficiency in Mombasa guinegrass (Panicum maximum cv. mombasa) at dry and rainy seasons
}

\section{Fernando Shintate Galindo*, Salatiér Buzetti, Marcelo Carvalho Minhoto Teixeira Filho, Elisângela Dupas, Mariana Gaioto Ziolkowski Ludkiewicz}

\author{
Department of Plant Health, Rural Engineering, and Soils, Faculdade de Engenharia de Ilha Solteira, \\ Universidade Estadual Paulista "Júlio de Mesquita Filho", Ilha Solteira, Sao Paulo State, Zip Code 15385-000, \\ Brazil
}

*Corresponding author: fs.galindo@yahoo.com.br

\begin{abstract}
Nitrogen is the nutrient that most influences productivity and pasture quality but nitrogen fertilization efficiency still needs to be increased. The objective of this work was to study the efficiency of nitrogen sources and doses $(\mathrm{N})$ on the yield of Panicum maximum cv. Mombasa applied during rainy and dry periods. The soil of the experimental area is an ultisol with a sandy texture. The experimental design was a randomized block in a factorial scheme with four replications, two sources of nitrogen: urea and ammonium nitrate and five $\mathrm{N}$ doses $\left(0,50,100,150\right.$ and $200 \mathrm{~kg} \mathrm{ha}^{-1}$ per cutting), in total $0,300,600,900$ and $1200 \mathrm{~kg}$ ha ${ }^{-1}$ per season-dry or rainy, respectively). The dry matter yield (DMY) and nitrogen use efficiency (NUE), agronomic efficiency (AE), recovery of applied nitrogen (RAN) and physiological efficiency (PE) were evaluated. The results showed that $\mathrm{N}$ source did not influence DMY, NUE, AE, RAN and PE. However, the N doses influenced DMY positively, and negatively NUE, AE, RAN and PE. Generally, the increase was occurred in DMY with the increase of $\mathrm{N}$ doses and decrease in NUE, AE, RAN and PE. As the N source did not influence the analyzed attributes, it is recommended to use urea, because it is a fertilizer with the highest $\mathrm{N}$ concentration and lowest cost per unit of nutrient, at a dose of $100 \mathrm{~kg} \mathrm{ha}^{-1}$ per cut, favoring DMY gain. In addition this urea assists with the management and maintenance of the Mombasa guineagrass.
\end{abstract}

Keywords: Ammonium nitrate, Efficiency of nitrogen fertilization, Pasture, Tropical grass, Urea.

Abbreviations: DMY_dry matter yield; NUE_nitrogen use efficiency; AE_agronomic efficiency; RAN_recovery of applied nitrogen; PE_physiological efficiency.

\section{Introduction}

Brazil has about 180 million hectares of pastures and is one of the largest commercial producers of world cattle, which depends on the pasture (Silva et al., 2009). Thus, pastures in Brazil are extremely important for production of beef due to the wide territorial extension of pasture areas established in the country. Pastures are considered the base of the feed, since they are less costly to produce animal protein human consumption (Fernandes et al., 2015). This is possible because of climatic factors favoring the production of fodder in the different locations and periods of the year. However, forage plants usually do not receive fertilization and over the years lose their development potential, reducing their quality and productivity (Benett et al., 2008). Usually, he pasture degradation occurs after a few years (Silveira et al., 2010).

Several species are used in pasture formation in Brazil and among them the mombasa is widely used in breeding and rearing of cattle. The grass species Panicum maximum (syn. Megathyrsus maximus) presents one of the greatest potential production of dry matter (DM) in subtropical and tropical environments that are known and can reach annual production of dry matter around $33 \mathrm{t} \mathrm{ha}^{-1}$ (Freitas et al., 2007). Proper management of soil fertility and knowledge of the nutritional requirements of this grass are extremely important to the practice of pasture management, which reflects in higher productivity and availability of food for the animals (Euclides et al., 2007; Silva et al., 2009; Barth Neto et al., 2010; Silveira et al., 2010; Pereira et al., 2012).

Most of Brazilian pastures present some degree of degradation, being necessary conservation practices, such as adoption of new species and fertilization, especially nitrogen (N) to improve their conditions. Pastures for animal production in Brazil present low technology use mainly in the Cerrado region, where approximately $40 \%$ of the Brazilian livestock population is concentrated (IBGE, 2006). The use of pasture fertilization practices has resulted in higher performance indices as a result of higher forage supply, both in quantity and quality (Silva et al., 2013).

$\mathrm{N}$ is an important constituent of proteins, besides maximizing the dry matter yield of forage grasses, being the main nutrient for the maintenance of their productivity. When applied, it is assimilated by the plant and associates with the carbon chains, promoting the increase of the cellular constituents and consequently increasing the vigor of the regrowth and the total green dry matter production of the plants under favorable climatic conditions (Van Soest, 1994).

Changes in the amount of nitrogen available in the system and in the nitrate $\left(\mathrm{N}-\mathrm{NO}^{3-}\right)$ : ammonium $\left(\mathrm{N}-\mathrm{NH}^{4+}\right)$ ratio of the soil solution affect the recovery and efficiency of nitrogen use, dry matter yield and chemical composition of pastures (Primavesi et al., 2006a; Silva et al., 2013; Silveira et al., 
2013). Therefore, studies of evaluation of use and efficiency of nitrogen fertilizers, applied at different times, are important. They result in greater knowledge about the use of the input by the crops, making possible its economic use. According to Euclides et al. (2007), several studies have demonstrated significant increases in the production of Panicum maximum with the supply of N. Although most of these experiments present linear responses, their magnitudes are varied. Thus, there is a need to develop studies on $\mathrm{N}$ sources and doses applied and the frequency and efficiency of their supply to better understand the productive response of forages in dry and rainy seasons.

Based on above, the objective of this work was study the efficiency of nitrogen sources and doses, applied in rainy and dry seasons, evaluating dry matter yield, nitrogen use efficiency, agronomic efficiency, recovery of applied nitrogen and physiological efficiency of Panicum maximum cv. Mombasa in the Brazilian Cerrado region of Northwest of São Paulo State.

\section{Results}

\section{Dry matter yield in dry and rainy season}

$\mathrm{N}$ doses and sources did not influence DMY and NUE of Mombasa guineagrass, both in dry and rainy season (Table 1). The interaction between doses and sources was significant for both DM accumulated in the dry season as rainy season (Tables 2 and 3). It was adjusted to the increasing linear function for doses using the $\mathrm{N}$ doses as urea and ammonium nitrate in both (Fig 2). The increase of DM in control $(0 \mathrm{~kg}$ $\left.\mathrm{ha}^{-1} \mathrm{~N}\right)$ and higher dose $\left(1,200 \mathrm{~kg} \mathrm{ha}^{-1} \mathrm{~N}\right)$ in the dry and rainy periods was $2,422 \mathrm{~kg} \mathrm{ha}^{-1}$ and $5,347 \mathrm{~kg} \mathrm{ha}^{-1}$, respectively, representing 25.88 and $24.36 \%$ of increase. On average, the $\mathrm{DM}$ of the rainy season was $131.31 \%$ higher than the dry period, varying in 11,013 and $25,474 \mathrm{~kg} \mathrm{ha}^{-1}$, respectively. This reveals the problem related to the lack of forage for cattle in the dry season, which is the main limiting factor of livestock in Central Brazil.

\section{Mombasa guineagrass nitrogen use efficiency (NUE) in dry and rainy season}

In relation to nitrogen use efficiency (NUE), the maximum dose of 1,200 $\mathrm{kg} \mathrm{ha}^{-1}$ applied in dry season provided higher nitrogen use efficiency, although the difference in the dose that provided the lowest NUE ( $900 \mathrm{~kg} \mathrm{ha}^{-1}$ ) was very small ( 0.0832 to $0.0937 \mathrm{~kg}^{2}$ ) accumulated $\mathrm{N} \mathrm{per}^{-1} \mathrm{DM}$. Similar to dry season, in rainy season the numerical difference between the dose with the lowest NUE $\left(1,200 \mathrm{~kg} \mathrm{ha}^{-1}\right)$ for the highest dose $\left(600 \mathrm{~kg} \mathrm{ha}^{-1}\right)$ was very small, ranging from 0.2234 to $0.2971 \mathrm{~kg}^{2}$ accumulated $\mathrm{N}$ per $\mathrm{g}^{-1} \mathrm{DM}$ (Table 1 ).

\section{Mombasa guineagrass agronomic efficiency $(A E)$ in dry and rainy season}

The agronomic efficiency was influenced by $\mathrm{N}$ doses, where the increase of the doses affected the AE negatively (Table 4). There was adjustment of decreasing linear function for dry and rainy season (Fig 3). The results support the hypothesis that increasing nitrogen doses affect pasture characteristics and the agronomic efficiency of nitrogen in pasture.

\section{Recovery of applied nitrogen $(R A N)$ in dry and rainy season}

Recovery of nitrogen was negatively influenced by doses in dry season, where the increase of $\mathrm{N}$ doses linearly reduced the RAN. In rainy season, the doses influenced RAN in a different way (Table 4). There was adjustment to quadratic function (Fig 3), whereas the maximum point was reached at $777 \mathrm{~kg} \mathrm{ha}^{-1}$ showing the RAN increase of $27.8 \%$. The increase of the applied $\mathrm{N}$ dose (control to $600 \mathrm{~kg} \mathrm{ha}^{-1}$ ) provided enough amount of this nutrient for absorption and utilization by the grass, when a greater amount of $\mathrm{N}$ was added. The plant $\mathrm{N}$ requirements have possibly been supplied, negatively influencing the recovery and consequent recovery of applied nitrogen.

$\mathrm{N}$ sources influenced the RAN rate (Table 4), where ammonium nitrate was higher than urea in the dry period and in the rainy season. However, Primavesi et al. (2006b), working with $\mathrm{N}$ doses with ammonium nitrate and urea sources in Marandu palisadegrass, verified that the recovery of $\mathrm{N}$ applied varied with the sources and doses of $\mathrm{N}$, showing that with the increase of $\mathrm{N}$ doses, there was a decrease in $\mathrm{N}$ recovery for both sources, being higher for the source of ammonium nitrate.

\section{Mombasa guineagrass physiological efficiency in dry and rainy season}

In relation to the physiological efficiency, the $\mathrm{N}$ doses negatively influenced, where for the dry period there was an adjustment to the decreasing linear function (Fig 3) and for rainy season there was an adjustment to the quadratic function, with a minimum point with $647 \mathrm{~kg} \mathrm{ha}^{-1}$. N sources as well as the interaction between source and doses did not influence PE (Table 4).

\section{Discussion}

Nitrogen fertilization generally increased the forage DMY considerably (Mazza et al., 2009). This is explained by the fact that nitrogen fertilization accelerates growth, tillering, leaf production and, consequently, the expansion of the aerial part and root system. The results obtained are in agreement with those found by Corrêa et al. (2007), who observed an increase in DMY according to the increase of $\mathrm{N}$ doses $(0,25$, 50,100 and $200 \mathrm{~kg} \mathrm{ha}^{-1}$ per cut).

A number of studies have reported the positive effect of nitrogen fertilization on pasture (Benett et al., 2008, Dupas et al., 2010, Batista et al., 2014). However, Fernandes et al. (2015) suggested that it is possible that the soil can supply the $\mathrm{N}$ requirement of the forage grasses depending on the soil type and management of the area, reaching a good productive level. In the present study, the $\mathrm{N}$ reserves in the soil were not sufficient to supply the nutrient demand for efficient growth of Mombasa guineagrass, and in this way the nitrogen fertilization becomes fundamental to reach high yields.

The amount of dry matter produced as a function of the nitrogen fertilization was considered satisfactory to guarantee the stability of the lawn and the animal production, once the values obtained were superior to $1,600 \mathrm{~kg} \mathrm{ha}^{-1}$ per cut, which is recommended by Fernandes et al al. (2015) as sufficient to ensure satisfactory forage consumption. However, such value may vary according to the utilization rate and period or 
Table 1. Dry matter yield (DMY) of Mombasa guineagrass and nitrogen use efficiency (NUE) in dry and rainy season, as a function of N doses and rates. Ilha Solteira - SP, Brazil, 2012 to 2014.

\begin{tabular}{|c|c|c|c|c|}
\hline & Dry season & Rainy season & Dry seaso & Rainy season \\
\hline $\begin{array}{l}\mathrm{N} \text { doses } \\
\left(\mathrm{kg} \mathrm{ha}^{-1}\right)\end{array}$ & \multicolumn{2}{|c|}{ DMY $\left(\mathrm{kg} \mathrm{ha}^{-1}\right)$} & $\begin{array}{l}\text { NUE (k } \\
\text { accumula }\end{array}$ & MS $\mathrm{g}^{-1}$ of $\mathrm{N}$ \\
\hline 0 & 9,358 & 21,948 & 0.0862 & 0.2648 \\
\hline 300 & 10,518 & 23,985 & 0.0834 & 0.2534 \\
\hline 600 & 11,423 & 25,775 & 0.0930 & 0.2971 \\
\hline 900 & 11,988 & 28,368 & 0.0832 & 0.2553 \\
\hline 1200 & 11,780 & 27,295 & 0.0937 & 0.2234 \\
\hline \multicolumn{5}{|l|}{$\mathrm{N}$ sources } \\
\hline Urea & $10,938 \mathrm{a}$ & $25,150 \mathrm{a}$ & $0.0941 \mathrm{a}$ & $0.2686 \mathrm{a}$ \\
\hline Ammonium nitrate & $11,088 \mathrm{a}$ & $25,798 \mathrm{a}$ & $0.0817 \mathrm{a}$ & $0.2490 \mathrm{a}$ \\
\hline L.S.D. (5\%) & 906.5 & $1,778.2$ & 0.0158 & 0.0360 \\
\hline Overall Mean & 11,013 & 25,474 & 0.0879 & 0.2588 \\
\hline C.V. (\%) & 12.69 & 10.76 & 17.72 & 13.76 \\
\hline
\end{tabular}

Means followed by the same letter in column do not differ by Tukey test, at $5 \%$ probability.

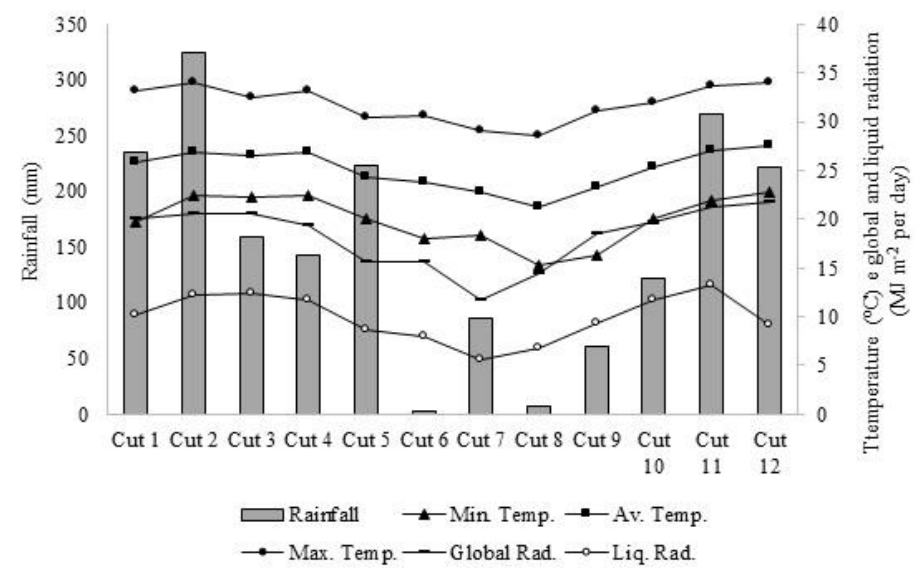

Fig 1. Climate data obtained from the weather station located at the study site in Ilha Solteira - SP. Period December 2012 to January 2014.

Table 2. Interaction between doses and sources related to the productivity of dry matter accumulation of mombasa guineagrass in the dry period. Ilha Solteira - SP, Brazil, 2012 to 2014

\begin{tabular}{|c|c|c|c|c|c|}
\hline \multirow{2}{*}{ Sources } & \multicolumn{5}{|c|}{ Doses $\left(\mathrm{kg} \mathrm{ha}^{-1}\right)$} \\
\hline & 0 & 300 & 600 & 900 & 1200 \\
\hline Urea $^{* * *}$ & $9,820 \mathrm{a}$ & $10,540 \mathrm{a}$ & $10,745 \mathrm{a}$ & $12,025 \mathrm{a}$ & $11,560 \mathrm{a}$ \\
\hline A.N. ${ }^{* * *}$ & $8,895 \mathrm{a}$ & $10,495 \mathrm{a}$ & $12,100 \mathrm{a}$ & $11,950 \mathrm{a}$ & $12,000 \mathrm{a}$ \\
\hline L.S.D. (5\%) & 2,027 & & & & \\
\hline
\end{tabular}

Means followed by the same letter in the column do not differ by Tukey test at $5 \%$ probability. $* *$ Significant $\mathrm{p}<0.01 *$ significant $0.01<\mathrm{p}<0.05 \mathrm{~ns}$ : not significant AN: Ammonium nitrate.

A
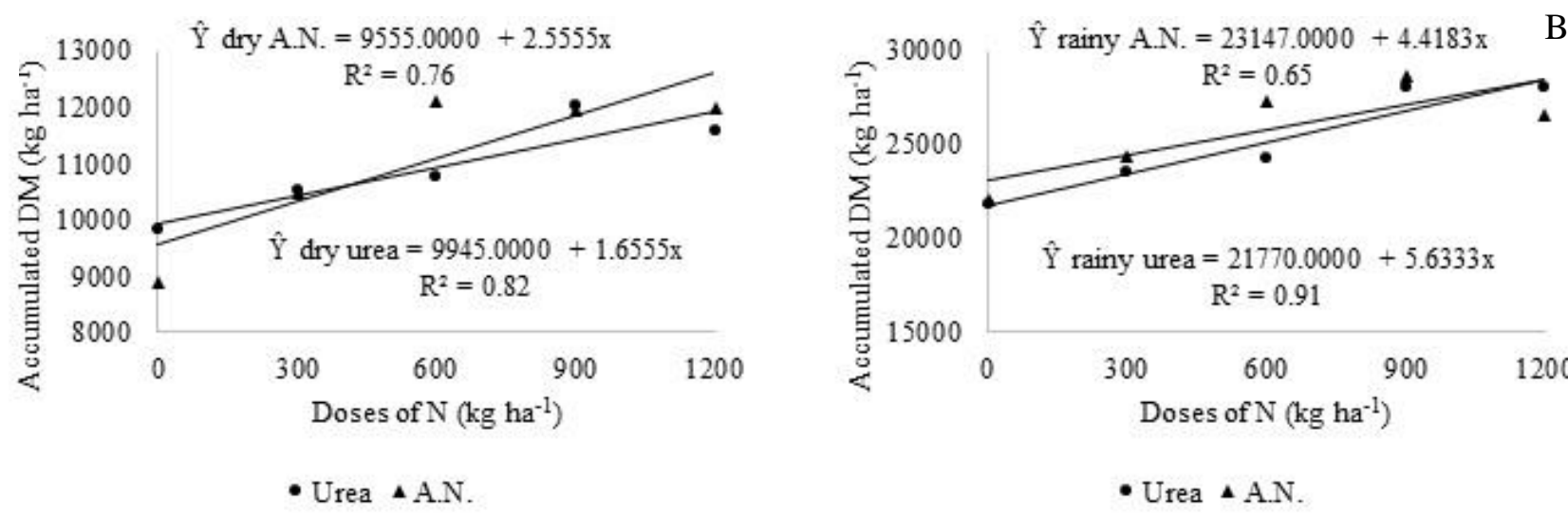

Fig 2. Breakdown of interaction between doses and sources in accumulated dry matter of mombasa in the dry period (A); unfolding of the interaction between doses and sources in accumulated dry matter mombasa in the rainy season (B). Ilha Solteira - SP, Brazil, 2012 to 2014 
Table 3. Interaction between doses and sources related to the productivity of dry matter accumulation of mombasa guineagrass in the rainy season. Ilha Solteira - SP, Brazil, 2012 to 2014.

\begin{tabular}{|c|c|c|c|c|c|}
\hline \multirow{2}{*}{ Sources } & \multicolumn{5}{|c|}{ Doses $\left(\mathrm{kg} \mathrm{ha}^{-1}\right)$} \\
\hline & 0 & 300 & 600 & 900 & 1200 \\
\hline Urea $^{* * x}$ & $21,835 \mathrm{a}$ & $23,585 \mathrm{a}$ & $24,215 \mathrm{a}$ & $28,075 \mathrm{a}$ & $28,040 \mathrm{a}$ \\
\hline A.N. ${ }^{* *}$ & $22,060 \mathrm{a}$ & $24,385 \mathrm{a}$ & $27,335 \mathrm{a}$ & $28,660 \mathrm{a}$ & $26,550 \mathrm{a}$ \\
\hline L.S.D. $(5 \%)$ & 3,976 & & & & \\
\hline
\end{tabular}

Means followed by the same letter in the column do not differ by Tukey test at $5 \%$ probability. $* *$ Significant $\mathrm{p}<0.01 *$ significant $0.01<\mathrm{p}<0.05$ ns: not significant, AN: Ammonium nitrate.

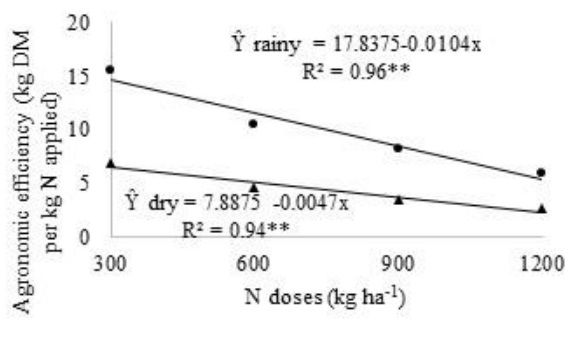

$\Delta$ Dry $\bullet$ Rainy

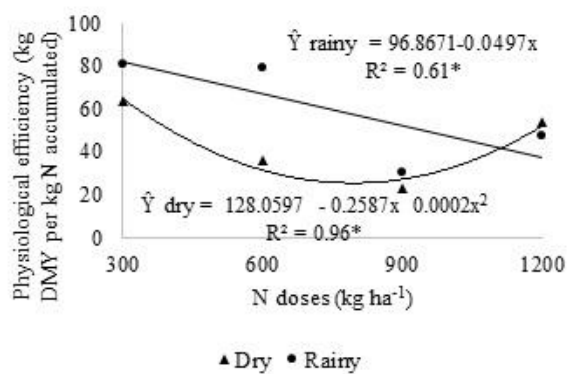



$\Delta$ Dry $\bullet$ Rainy

Fig 3. Agronomic efficiency (AE) (A), recovery of applied nitrogen (RAN) (B) and physiological efficiency (PE) (C) of Mombasa guineagrass in dry and rainy seasons, in function of N doses. Ilha Solteira - SP, Brazil, 2012 to 2014.

Table 4. Agronomic efficiency (AE), recovery of applied nitrogen (RAN) and physiological efficiency (PE) of Mombasa guineagrass in dry and rainy seasons, as a function of $\mathrm{N}$ doses and sources. Ilha Solteira - SP, Brazil, 2012 to 2014.

\begin{tabular}{|c|c|c|c|c|c|c|}
\hline & Dry season & Rainy season & Dry season & Rainy season & Dry season & Rainy season \\
\hline $\begin{array}{l}\mathrm{N} \text { doses } \\
\left(\mathrm{kg} \mathrm{ha}^{-1}\right)\end{array}$ & \multicolumn{2}{|c|}{$\begin{array}{l}\mathrm{AE} \mathrm{(kg} \mathrm{of} \mathrm{DM} \mathrm{kg} \\
\text { per } \mathrm{N} \text { applied)\# }\end{array}$} & \multicolumn{2}{|l|}{ RAN (\%)\# } & \multicolumn{2}{|c|}{$\begin{array}{l}\mathrm{EF}(\mathrm{kg} \text { of DM kg-1 } \\
\text { per } \mathrm{N} \text { accumulated)\# }\end{array}$} \\
\hline 300 & 6.91 & 15.48 & 15.25 & 20.59 & 63.69 & 81.04 \\
\hline 600 & 4.59 & 10.56 & 14.54 & 26.81 & 35.83 & 79.27 \\
\hline 900 & 3.44 & 8.23 & 10.92 & 25.34 & 22.97 & 30.58 \\
\hline 1200 & 2.64 & 5.84 & 8.10 & 20.17 & 53.80 & 47.61 \\
\hline \multicolumn{7}{|l|}{$\mathrm{N}$ sources } \\
\hline Urea & $4.00 \mathrm{a}$ & $8.82 \mathrm{a}$ & $7.96 \mathrm{~b}$ & $18.21 \mathrm{~b}$ & $46.69 \mathrm{a}$ & $58.85 \mathrm{a}$ \\
\hline Ammonium nitrate & $4.79 \mathrm{a}$ & $11.23 \mathrm{a}$ & $16.45 \mathrm{a}$ & $28.25 \mathrm{a}$ & $41.45 \mathrm{a}$ & $60.41 \mathrm{a}$ \\
\hline L.S.D. (5\%) & 1.86 & 3.58 & 7.87 & 4.41 & 28.48 & 31.08 \\
\hline Overall Mean & 4.39 & 10.03 & 12.20 & 23.23 & 44.07 & 59.63 \\
\hline C.V. $(\%)$ & 29.43 & 20.87 & 31.70 & 6.84 & 27.11 & 23.35 \\
\hline
\end{tabular}

Means followed by the same letter in column do not differ by Tukey test, at $5 \%$ probability \# Data corrected following equation $(\mathrm{x}+0.5)^{0.5}$ for data normalization.

season of the year, justifying the magnitude of response to nitrogen fertilization in different cuts. Tropical grasses such as Mombasa guineagrass, present high DMY, resulting in forage surplus. As observed in this study, in the summer and autumn seasons the DMY provided satisfactory consumption with surpluses, which can be used in the form of silage for use in times of food shortage. Another alternative would be the fodder fencing technique, which plays an important role in the nutritional management of the animals, allowing their surpluses to be used in periods of accelerated growth, since changes in the quantity of animals per unit area are generally difficult to manage (Evangelista et al., 2004). As the $\mathrm{N}$ sources (Table 1), the results agree those found by Silveira et at. (2015), working with the $\mathrm{N}$ sources: ammonium nitrate, ammonium sulfate, urea, urea treated with Agrotain, Super N and ammonium sulfonitrate and $\mathrm{N}$ doses $(0,60$ and $120 \mathrm{~kg}$ $\mathrm{ha}^{-1}$ per year) in grass-bahia (Paspalum notatum). Fernandes et al. (2015), studied the urea sources such as ammonium sulfonitrate, ammonium nitrate, ammonium sulfate and sulfammo at doses of $0,50,100,150$ and $200 \mathrm{~kg} \mathrm{ha}^{-1}$ by cutting mombasa guineagrass, and found no difference among the sources on productivity. With respect to NUE, Silva et al. (2011) verified that the NUE was not influenced by $\mathrm{N}$ doses and sources, but observed a significant effect of doses and years of pasture recovery. NUE increased with the increase of applied $\mathrm{N}$ doses and their values ranged from 0.2119 (in the year 2005 without application of $\mathrm{N}$ ) to 0.5260 $\mathrm{kg}^{2}$ accumulated $\mathrm{N}$ per $\mathrm{g}^{-1} \mathrm{DM}$ (in the year 2004 at the 
maximum dose), showing a difference of $61 \%$ when compared. The highest NUEs were observed at 345, 272 and $203 \mathrm{~kg} \mathrm{ha}^{-1}$ per year for the years 2004, 2005 and 2006, showing an increase of 144,126 and $51.8 \%$ in relation to the non-application of nitrogen, respectively (Silva et al., 2011). It verified higher values than those found in the present study, although the doses employed in this work were much higher, possibly resulting in higher losses due to volatilization and leaching, and lower utilization and $\mathrm{N}$ efficiency.

Regarding the low NUE observed in this work, the $\mathrm{N}$ use efficiency for food production in the world is very low and $\mathrm{N}$ recovery of nitrogen fertilizers can vary among plant species, management practices, soil properties, environmental conditions and applied N sources (Pegoraro et al., 2009; Espindula et al., 2010). Thus, the maximization of $\mathrm{N}$ fertilizer conversion efficiency in forage dry matter is extremely important for the final bioeconomic result of nitrogen fertilization in pastures (Martha Júnior et al., 2009).

Regarding to AE, similar results were found by Freitas et al. (2005), which verified a significant effect for $\mathrm{N}$ doses, cut off times and for the interaction of $\mathrm{N}$ doses and cut times in relation to $\mathrm{AE}$. A decrease in $\mathrm{AE}$ was observed as the $\mathrm{N}$ doses were increased at all cutting times and with the cut effectiveness, indicating that this decrease was probably due to the lower nitrogen utilization by the plants. This usually happens as a function of losses of this nutrient by leaching or volatilization with the use of the highest doses as a consequence of high precipitations that occurres during the experimental period. The results also corroborate with Costa et al. (2010), who found better AE using the lowest $\mathrm{N}$ dose. Similar results were obtained by Ruggiero et al. (2006), who found better AE in lowest $\mathrm{N}$ dose $\left(100 \mathrm{~kg} \mathrm{ha}^{-1}\right)$ and lower AE at the highest $\mathrm{N}$ dose $\left(400 \mathrm{~kg} \mathrm{ha}^{-1}\right)$. Primavesi et al. (2006a) evaluated $\mathrm{AE}$ in coast-cross grass and found variable efficiency as a function of the $\mathrm{N}$ doses with decreases in efficiencies as $\mathrm{N}$ doses increased.

In rainy season, $\mathrm{AE}$ was numerically superior compared to dry season, probably due to better rainfall distribution, favoring the solubilization of the nitrogen fertilizers in soil. It contributes to the agronomic efficiency increase, resulting in a higher dry matter yield (Costa et al,. 2010).

Studying agronomic efficiency in Marandu palisadegrass, Primavesi et al. (2006a) verified that the best indices occurred when the lowest $\mathrm{N}$ doses were applied, with a reduction in the values of these indices with the increase of $\mathrm{N}$ doses. Researches show that the agronomic efficiency of $\mathrm{N}$ in forage yield is usually reduced with increment of $\mathrm{N}$ fertilization in pastures (Fagundes et al., 2006; Silveira et al., 2007; Mello et al., 2008; Canto et al., 2013), which is consistent with the results obtained in the present study.

Agronomic $\mathrm{N}$ efficiency in forages, especially in Panicum maximum species has been reported in the literature. It has shown variations of 10 to $90 \mathrm{~kg}$ of DM produced per $\mathrm{kg}$ of nitrogen applied, a range in which the data verified in this work as well. In addition, Martha Júnior et al. (2009) reported that the amplitude of forage production resulting from the use of nitrogen fertilizer depends on the factors such as nitrogen doses, use of other nutrients, history of the area (including the residual effect of fertilization), management of pasture, nitrogen-fertilizer management strategy adopted as the forms of subdivision and the climate and soil characteristics of the region, which interfere both in the ability of the plant to respond to nitrogen fertilizer and in the recovery and loss of nitrogen fertilizer applied. According to the authors, the efficiency of nitrogen conversion in forage masses in pasture of tropical grasses has reached the values of up to $83 \mathrm{~kg}$ MS $\mathrm{kg}^{-1}$ of nitrogen applied. However on average, the efficiency of $26 \mathrm{~kg} \mathrm{DM} \mathrm{kg}^{-1}$ of nitrogen, and even greater efficiencies, has been occurred with the application of $150 \mathrm{~kg} \mathrm{ha}^{-1}$ nitrogen (Sant'Ana et al., 2011).

Regarding the RAN, the lower N use (RAN) was expected with increasing doses due to higher dry matter yield (Costa et al., 2010), nutrient concentration (Costa et al., 2009a), and $\mathrm{N}$ extraction by plants (Costa et al., 2009b) in the highest doses applied. Therefore, in these higher doses there is a greater chance of nutrient losses through volatilization, leaching, denitrification and surface washing.

According to Silva et al. (2011), other aspects that possibly contribute to the reduction of RAN may have influenced this work such as time of forage sampling and the sampling of only leaves and stems above $20 \mathrm{~cm}$ without evaluating the accumulated $\mathrm{N}$ in the roots and aerial parts. In the evaluation of RAN, it is important to point out that in addition to the losses of $\mathrm{N}$ applied by the mentioned processes. The plants are actually in competition with the soil microbial population, and $\mathrm{N}$ applied to the soil is also subject to transformations mediated by microorganisms, which shows the equilibrium relationships between organic and inorganic forms and the ionic forms of $\mathrm{NO}_{3-}$ and $\mathrm{NH}_{4+}$ are absorbed by plants (Moreira and Siqueira, 2006).

In contrast, Silva et al. (2011) observed that RAN was influenced by doses and years of pasture recovery, presenting a linear reduction with the increase of $\mathrm{N}$ doses for 2004 year, and decreasing quadratic for the years 2005 and 2006. The results have shown that RAN rate decreases with the increase of applied dose to the soil (Primavesi et al., 2006a).

Whitehead (1995) found that the recovery of fertilizer applied to pastures ranged from 50 to $80 \%$ and more frequently from 65 to $70 \%$ higher than those found in the present study. According to Corsi (1994), nitrogen recovery may be greater than $80 \%$ in tropical grasses, indicating that the fertilizer is properly applied. The values of RAN can reach high values to exceed $100 \%$. This is due to the calculation of RAN, when the difference of $\mathrm{N}$ in soil and the applied fertilizer is not considered (Martha Júnior et al., 2009). Therefore, the environmental impact is positive and nitrogen losses due to leaching are not of concern, when nitrogen levels normally absorbed by the plants and when the water table is not superficial (Primavesi et al., 2006a).

For the genus Panicum maximum, Favoretto et al. (1988) reported that the RAN values may vary from $23 \%$ to $81 \%$, a range higher than that reported in this study. This implies that the RAN rate was not considered satisfactory in light of the information in the literature. According to Primavesi et al. (2006a), this index is easy to estimate and low cost, since it uses only the total $\mathrm{N}$ content of the plant and the forage dry matter of fertilized and non-fertilized plots. In intensively managed pastures, where high $\mathrm{N}$ doses are used, knowledge on the recovery of $\mathrm{N}$ by plants becomes important to maximize the efficiency of their use and minimize its environmental impact.

There is a consensus among the authors that ammoniacal salts, such as ammonium sulfate, present lower losses of N$\mathrm{NH}_{3}$ - by volatilization than urea (Martha Júnior et al., 2009). While ammoniacal salts present volatilization losses between 5 and $10 \%$ of the applied $\mathrm{N}$, the urea usually loses around 10 to $25 \%$ and can reach, up to $80 \%$ under favorable conditions. However, this assumption was not verified in this work.

With respect to PE, similar result was reported by Silva et al. (2011), studying pasture recovery in Marandu palisadegrass. They observed that the sources did not influence PE and reported a significant difference for doses and years of pasture recovery in the PE, where for all the years of recovery there was a linear reduction of PE with increase in applied $\mathrm{N}$ doses. The highest values of $\mathrm{PE}$ were observed in doses of $100 \mathrm{~kg} \mathrm{ha}^{-1}$ per year and the lowest in 
the maximum dose in all evaluated years. PE values varied in range of $29.49 \mathrm{~kg}$ of DM kg ko $^{-1}$ to.02 kg of DM kg-1 of accumulated $\mathrm{N}$, presenting a difference of $56 \%$, a variation close to that verified in the present work (from 22.97 to 81.04 $\mathrm{kg}$ of DM kg-1 of accumulated $\mathrm{N}$ ).

\section{Materials and methods}

\section{Location and management history}

The experiment was conducted in the region of Ilha Solteira SP, located on the left bank of the Paraná river, with coordinates 2021 'South latitude and 51 22' West longitude, Altitude of $326 \mathrm{~m}$, in an area previously occupied by $P$. maximum cv. Mombasa undergrazing since 2006. The soil was classified as an Ultisol, sandy texture (Embrapa, 2013). Total precipitation during the experiment time was 1,320 $\mathrm{mm}$, the average air humidity was $70 \%$, while the average temperature was $25.3{ }^{\circ} \mathrm{C}$, ranging in average minimum and maximum temperatures from 19.8 to $32.2{ }^{\circ} \mathrm{C}$. The climate type is Aw according to Koppen characterized as humid tropical with rainy season in summer and dry in winter. In Fig 1, there is the average weather data for each cut done.

The soil sample on depth $0-20 \mathrm{~cm}$ was collected before the cut of the grass in 2012 to determine the chemical characteristics of the soil, with the following results: $\mathrm{P}$ resin $=13 \mathrm{mg} \mathrm{dm}^{-3}, \mathrm{pH} \mathrm{CaCl}_{2}=5.2 ; \mathrm{K}, \mathrm{Ca}, \mathrm{Mg}, \mathrm{Al} \mathrm{H}+, \mathrm{SB}, \mathrm{CEC}$ $=2.2,35.0,7.0,16.0,27.0,48.0 \mathrm{mmol}_{\mathrm{c}} \mathrm{dm}^{-3}$, respectively, O.M. $=25 \mathrm{~g} \mathrm{dm}^{-3}$ and $\mathrm{V}=56 \%$.

\section{Treatments and experimental design}

The experimental design was a randomized block with ten treatments and four replicates with two N sources: urea (45\% $\mathrm{N}$ ) used as the nitrogen fertilizer, in which the $\mathrm{N}$ likely to be volatilized. The ammonium nitrate $(32 \% \mathrm{~N})$ was applied as comparative source. Five $\mathrm{N}$ doses were used for each source $\left(0,50,100,150\right.$ and $200 \mathrm{~kg} \mathrm{ha}^{-1}$, totaly $0,300,600,900$ and $1200 \mathrm{~kg} \mathrm{ha}^{-1}$ for a period), in a factorial scheme $2 \times 5$ (two sources and five $\mathrm{N}$ doses $)$. Each plot area was $6.0 \mathrm{~m}^{2}(3 \times 2$ $\mathrm{m})$ with $2 \mathrm{~m}$ spacing between then.

\section{Execution of the experiment}

The area was prepared with a plowing and two harrowing, and mombasa guinegrass was sown in January 2006. At the grass implantation, soil was corrected for fertility by applying $20 \mathrm{~kg} \mathrm{ha}^{-1}$ of N (urea). Phosphorus (P) and potassium (K) were based on theoretical doses to reach $\mathrm{P}$ values of $30 \mathrm{mg}$ $\mathrm{dm}^{-3}$ and $\mathrm{K}$ to $5 \%$ of CTC, using single superphosphate (18\% $\left.\mathrm{P}_{2} \mathrm{O}_{5}\right)$ and potassium chloride $\left(60 \% \mathrm{~K}_{2} \mathrm{O}\right)$.

The grass cutting and further growth evaluation were done on 12/07/2012 at $25 \mathrm{~cm}$ above the soil. The other cuts were done from December 2012 to January 2014. A $60 \mathrm{~kg} \mathrm{ha}^{-1}$ $\mathrm{K}_{2} \mathrm{O}$ was applied after every three cuts. Due to the amount and the number of cuts and better interpretation of the data, the sections were divided into periods of the year: dry season (04/20/2013; 05/25/2013; 06/28/2013; 08/03/2013; $09 / 26 / 2013$ and $11 / 01 / 2013)$ and rainy season (12/11/2013; $01 / 18 / 2014 ; 12 / 16 / 2012 ; 01 / 05 / 2013 ; 02 / 16 / 2013$ and 03/26/2013).

\section{Evaluations}

The sampling of aerial part of Mombasa guineagrass was performed manually at the center of the plot $25 \mathrm{~cm}$ above the soil level, covering the area of $0.5 \mathrm{~m}^{2}$ (metallic square $1 \mathrm{~m} \times$
$0.5 \mathrm{~m}$ ), for cutting aid an iron frame and at intervals based on grass height, varying by approximately 90 to $100 \mathrm{~cm}$. Overall, there was almost one cut per month, except for the first month due to low rainfall in the period that led to lower growth of the plant. The harvested forage was packed in paper bags and subsequently dried in forced circulation oven at air temperature about $65{ }^{\circ} \mathrm{C}$ for 72 hours. Then, the samples were weighted to quantify the DM (dry matter) produced in the representative area and ground in a Wiley Mill equipped with a screen with $1 \mathrm{~mm}$ sieve for subsequent analysis. After each cut the $\mathrm{N}$ doses were topdressed in each plot. The DM Mombasa guineagrass was calculated based on the amount of green matter $\left(\mathrm{kg} \mathrm{m}^{-2}\right)$, to obtain the original amount of dry matter

The efficiencies were calculated as follows: Nitrogen use efficiency $(\mathrm{NUE})=(\text { total dry matter }, \mathrm{kg})^{2} /(\mathrm{N}$ accumulated, $\mathrm{g}$ ); in (kg de MS) ${ }^{2} / \mathrm{g}$ of $\mathrm{N}$ acummulated (Siddiqi and Glass, 1981); Recovery of applied nitrogen (RAN) $=\mathrm{N}$ accumulated $(\mathrm{kg})$ with $\mathrm{N}$ fertilization $-\mathrm{N}$ accumulated $(\mathrm{kg})$ without $\mathrm{N}$ fertilization / $\mathrm{N}$ dose applied $(\mathrm{kg}) \times 100$; in \% (Fageria, 1998); Agronomic efficiency (AE) = Dry matter with fertilization $(\mathrm{kg})$ - dry matter without fertilization $(\mathrm{kg}) / \mathrm{N}$ dose (kg); in $\mathrm{kg}$ of DM / $\mathrm{kg} \mathrm{N}$ applied (Fageria, 1998); Physiological efficiency $(\mathrm{PE})=$ dry matter with fertilization $(\mathrm{kg})$ - dry matter without fertilization $(\mathrm{kg}) / \mathrm{N}$ accumulated with fertilization $(\mathrm{kg})$ - $\mathrm{N}$ accumulated without fertilization (kg); in $\mathrm{kg}$ of DM / kg de N accumulated (Fageria, 1998).

\section{Statistical analysis}

Data were subjected to the analysis of variance (F-test). For $\mathrm{N}$ sources Tukey's test for comparison of means, and to $\mathrm{N}$ doses regression analysis was used. Statistical analyzes were performed with the aid of SISVAR program (Ferreira, 2011).

\section{Conclusions}

Dry matter yield, nitrogen use efficiency, agronomic efficiency and physiological efficiency were similar for nitrogen sources, but ammonium nitrate provided higher recovery of applied nitrogen than urea, both in rainy and dry seasons. The increment of the nitrogen doses increased dry matter yield of Mombasa guineagrass in rainy and dry seasons and recovery of applied nitrogen in rainy season up to nitrogen dose $777 \mathrm{~kg} \mathrm{ha}^{-1}$, but caused a decrease in agronomic efficiency and physiological efficiency during both seasons, and recovery of applied nitrogen in dry season. As urea is a fertilizer with the highest nitrogen concentration and lowest cost-per-unit ratio of this nutrient, the use of urea at a dose of $100 \mathrm{~kg} \mathrm{ha}^{-1}$ per cut is recommended for the maintenance of pasture of mombasa guineagrass and obtaining satisfactory dry matter yield.

\section{References}

Barth Neto A, Boleta VS, Pancera Júnior EJ, de Almeida GM, do Canto, MW, Gasparino E, Baltazar LF (2011) Nitrogen and harvesting time on the components of forage and seed yield of guineagrass cultivar 'Mombaça'. Pesq Agropec Bras. 45:1312-1320. (In Portuguese, abstract in English)

Batista K, Giacomini AA, Gerdes L, Mattos WT, Colozza MT, Otsuk IP (2014) Influence of nitrogen on the production characteristics of ruzi grass. African J Agr Res. 9:533-538. 
Benett CGS, Buzetti S, Silva KS, Bergamaschine AF, Fabricio JA (2008) Yield and bromatologic composition of Marandu grass as function of sources and doses of nitrogen. Ci Agrotec. 32:1629-1636. (In Portuguese, abstract in English)

Canto MW, Hoeschl AR, Bona Filho A, Moraes A, Gasparino E (2013) Sward characteristics and agronomic efficiency of nitrogen on Tanzania grass under continuous grazing fertilized with nitrogen levels. Ci Rural. 43:682688. (In Portuguese, abstract in English)

Corrêa, L.A., Cantarella, H., Primavesi, A.C., Primavesi, O., Freitas, A.R., \& Silva, A.G. (2007) Effects of sources and rates of nitrogen on forage production and quality of coastcrossgrass. Rev Bras Zootecn. 36:763-772. (In Portuguese, abstract in English)

Corsi M (1994) Nitrogen fertilization of pastures. In: Symposium pastures, fundamentals of rational exploration, 2, Piracicaba. Anals Piracicaba: FEALQ, pp.121-153. (Printed version in Portuguese).

Costa KAP, Faquin V, Oliveira IP (2010) Nitrogen doses and sources on pasture recuperation of grass marandu. Arq Bras Med Vet Zootec. 62:192-199. (In Portuguese, abstract in English)

Costa KAP, Faquin V, Oliveira IP, Severiano EC, Oliveira MA (2009a) Doses and sources of nitrogen on mineral nutrition in marandu grass. Ci Animal Bras. 10:115-123. (In Portuguese, abstract in English)

Costa KAP, Faquin V, Oliveira IP, Severiano EC, Simon GA, Carrijo MS (2009b) Nutrient extraction of marandu grass under doses and nitrogen sources. Rev Bras Saúde Prod Animal. 10:801-812. (In Portuguese, abstract in English)

Dupas E, Buzetti S, Sarto AL, Hernandez FBT, Bergamaschine AF (2010) Dry matter yield and nutritional value of Marandu grass under nitrogen fertilization and irrigation in cerrado in São Paulo. Rev Bras Zootecn. 39:2598-2603.

Empresa Brasileira de Pesquisa Agropecuária - Embrapa (2013) National Soil Research Center. Brazilian system of soil classification. 3a ed. Brasília, DF: Embrapa, 353p. (Print version in Portuguese).

Espindula MC, Rocha VS, Souza MA, Grossi JAS, Souza LT (2010) Nitrogen application methods and doses in the development and yield of wheat. Ci Agrotec. 34:14041411. (In Portuguese, abstract in English)

Euclides VPB, Macedo MCM, Zimmer AH, Medeiros RN, Oliveira MP (2007) Pasture characteristics of Panicum maximum cv. Tanzânia fertilized with nitrogen in the end of summer. Pesq Agropec Bras. 42:1189-1198. (In Portuguese, abstract in English)

Fageria NK (1998) Optimizing nutrient use efficiency in crop production. Rev Bras Eng Agr Amb. 2:6-16. pdf (In Portuguese, abstract in English)

Fagundes JL, Fonseca DM, Mistura C, Morais RV, Vitor CMT, Gomide JA, Nascimento Júnior D, Casagrande DR, Costa LR (2006) Evaluation of structural characteristics of the signalgrass in a nitrogen fertilized pasture over the seasons of the year. Rev Bras Zootecn. 36:30-37. (In Portuguese, abstract in English)

Favoretto V, Rodrigues LRA, Tupinambá LF (1988) Nitrogen study on the production and bromatological composition of colony grass and their economic aspects. Científica. 16:71-78.

Fernandes JC, Buzetti S, Dupas, E, Teixeira Filho MCM, Andreotti M (2015) Sources and rates of nitrogen fertilizer used in Mombasa guineagrass in the Brazilian Cerrado region. African J Agric Res. 10:2076-2082.

Ferreira DF (2011) Sisvar: a computer statistical analysis system. Ci Agrotec. 35:1039-1042.
Freitas KR, Rosa B, Ruggiero JA, Nascimento JL, Heineman AB, Ferreira PH, Macedo R (2005) Evaluation of Mombaça grass (Panicum maximum Jacq.) under two different nitrogen rates. Acta Scientiarum: Agron. 27: 8389. (In Portuguese, abstract in English)

Freitas KR, Rosa B, Ruggiero JA, Nascimento JL, Heinemam AB, Macedo RF, Naves MAT, de Oliveira IP (2007) Avaliation of composition chemical - bromatologic by mombaça grass (Panicum maximum jacq.) submeted of differents doses by nitrogen. Bioscience J. 23:1-10. (In Portuguese, abstract in English)

Instituto Brasileiro de Geografia e Estatística - IBGE. Censo Agropecuário 2006. Rio de Janeiro: [s.nl.], 2007. Disponible at: 〈www.ibge.gov.br〉. Acess in: Jul. 5. 2013.

Martha Júnior GB, Corsi M, Trivelin PCO, Vilela L (2009) Recovery of $15 \mathrm{~N}$-urea in soil-plant system of tanzania grass pasture. Rev Bras Ci Solo. 33:95-101. (In Portuguese, abstract in English)

Mazza LM, Pôggere GC, Ferraro FP, Ribeiro CB, Cherobim VV, Motta ACV, Moraes A (2009) Nitrogen fertilization on biomass yield and chemical composition of mombaça grass on the first plateaux of Paraná. Scientia Agraria. 10:257-265. (In Portuguese, abstract in English)

Mello SQS, França AFS, Lanna AC, Bergamaschine AF, Klimann HJ, Rios LC, Soares TV (2008) Nitrogen fertilization on mombaçagrass: Yield, conversion efficiency and apparent recovery of nitrogen. Ci Animal Bras. 9:935947. (In Portuguese, abstract in English)

Moreira FMS, Siqueira JO (2006) Microbiology and soil biochemistry. 2.ed. atualized and amplified. Lavras: UFLA, 729p. (Print version in Portuguese)

Pegoraro RF, Mistura C, Wendling B, Fonseca DM, Fagundes JL (2009) Water and nitrogen management in the cultivation of elephant grass. Ci Agrotec. 33:461-467. (In Portuguese, abstract in English)

Pereira VV, Fonseca DM, Martuscello JA, Cecon PR, Santos MV, Braz TGS (2012) Biomass accumulation in mombasa guineagrass plants under different levels of nitrogen supply and plant densities. Rev Bras Zootecn. 41:1118-1126.

Primavesi AC, Primavesi O, Corrêa LA, Silva AG, Cantarella $\mathrm{H}$ (2006b) Nutrient content in marandu grass biomass due to nitrogen sources and levels. Ci Agrotec. 30:562-568. (In Portuguese, abstract in English)

Primavesi AC, Primavesi O, Corrêa LA, Silva AG, Cantarella H (2006a) Nitrate leaching in heavily nitrogen fertilized coastcross pasture. Rev Bras Zootecn. 35:683-690. (In Portuguese, abstract in English)

Ruggiero JA, Rosa B, Freitas KR, Nascimento JL (2006) Avaliation of sheets of water and levels nitrogenous of manuring on bromatologic composition in grass mombaça. Bioscience J. 22:9-19. (In Portuguese, abstract in English)

Sant'Ana EVP, Santos AB, Silveira PM (2011) The efficiency of use of nitrogen applied in top dressing in irrigated bean. Rev Bras Eng Agri Amb. 15:458-462. (In Portuguese, abstract in English)

Siddiqi MY, Glass ADM (1981) Utilization index: a modified approach to the estimation and comparison of nutrient utilization efficiency in plants. J Plant Nutr. 4:289-302.

Silva AG, França AFS, Miyagi ES, Mello SQS, Ferreira JL, Carvalho ER (2009) Proteins fractions of mombaça grass submitted to nitrogen doses at two cutting heights. Arq Bras Med Vet Zootec. 61:1148-1155. (In Portuguese, abstract in English)

Silva DRG, Costa KAP, Faquin V, Oliveira IP, Bernardes TF (2013) Rates and sources of nitrogen in the recovery of the structural and productive characteristics of marandu grass. Rev Ci Agron. 44:184-191. 
Silva DRG, Costa KAP, Faquin V, Oliveira IP, Souza MRF, Souza MAS (2011) Nutritional efficiency and nitrogen uptake by capim-marandu at pasture in moderate stage of degradation under doses and sources of nitrogen. $\mathrm{Ci}$ Agrotec. 35:242-249. (In Portuguese, abstract in English)

Silveira MCT, Da Silva SC, Sousa Jr. SJ, Barbero LM, Rodrigues CS, Limão VA, Pena KS, Nascimento Júnior D. (2013) Herbage acumulation and grazing losses on Mulato grass subjected to strategies of rotational stocking management. Scientia Agricola. 70:242-249.

Silveira MCT, Nascimento Júnior D, Cunha BAL, Difante GS, Pena KS, Silva SC, Sbrissia AF (2010) Effect of cutting interval and cutting height on morphogenesis and forage accumulation of guinea grass (Panicum maximum). Trop Grasslands, 44:103-108.
Silveira ML, Haby VA, Leonard A (2007) Response of Coastal Bermudagrass yield and nutrient uptake efficiency to nitrogen sources. Agron J. 99:707-714.

Silveira ML, Vendramini JMB, Sellers B, Monteiro FA, Artur AG, Dupas E (2015) Bahiagrass response and N loss from selected $\mathrm{N}$ fertilized sources. Grass Forage Sci. 70:154-160.

Soest PJ van (1994) Nutritional ecology of the ruminant. 2. ed. Ithaca: Cornell Universtity, 476p.

Whitehead DC (1995) Volatilization of ammonia. In: Whitehead DC (ed.) Grassland nitrogen. CAB International, Wallingford, England. pp. 152-179. 